\title{
有棘細胞癌の全身転移
}

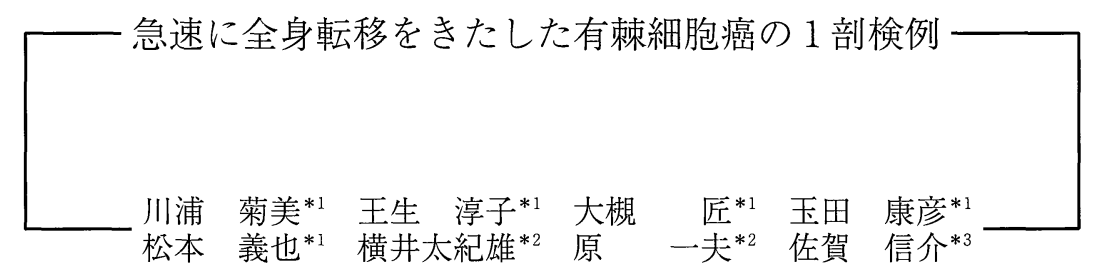

\section{An autopsy case of squamous cell carcinoma with metastases rapidly spreading throughout the body}

Kikumi KAWAURA *1, Junko IKURUMI ${ }^{* 1}$, Takumi OOTSUKI ${ }^{* 1}$, Yasuhiko TAMADA *1, Yasunari MATSUMOTO ${ }^{* 1}$, Takio YOKOI ${ }^{* 2}$, Kazuo HARA *2, Sinsuke SAGA *3

*1 Department of Dermatology, Aichi Medical University

*2 Division of Pathology, Aichi Medical University Hospital

*3 The Second Department of Pathology, Aichi Medical University

Three years before presenting at our hospital at the age of 57 , this male patient was examined by a local doctor for sudden elevations in part of an erosive plaque located on the lower right leg. At the time of presentation, there was a $6 \mathrm{~cm}$ plaque from dark brown to pink in color on the right lower leg, in the central to somewhat lower part of which was a $3 \mathrm{~cm}$ tumor. Histologically, this presented an image of Bowen's disease, and in the tumorous portion there were mixed eosinophilic-stained tumor cells and poorly differentiated basophilic-stained tumor cells. From the clinical picture and histological findings, the diagnosis was squamous cell carcinoma that had progressed from Bowen's disease. The tumor was excised. Metastasis to the right inguinal lymph nodes was discovered about 1 year after this excision, and soon metastases were discovered in organs throughout the body. The course was rapid, and the patient died 1 year later.

We conducted a clinical and histological investigation of the risk factors for metastasis in cases of skin squamous cell carcinoma. [Skin Cancer (Japan) 2001; 16 :340-344]

Key words : Squamous cell carcinoma, Metastasis, Autopsy

\section{はじめに}

今回我々は, stage II $\left(\mathrm{T}_{2} \mathrm{~N}_{0} \mathrm{M}_{0}\right)$ の有棘細胞

*1 愛知医科大学皮膚科

*2 愛知医科大学病院病理部

*3 愛知医科大学第 2 病理
癌（以下 SCC）に対し完全切除したにもかかわ らず術後約 1 年で転移を認め始め, その 1 年後 には死亡という急速な経過をたどった症例を経 
験し，剖検する機会を得たので報告する。

\section{症例}

患 者: 57 歳, 男性

初診: 2000 年 9 月 12 日

家族歴・既往歴：特記事項なし。

現病歴：1995年より右下腿にびらんが出現 し, 自分で消毒していたが 1998 年 8 月より一部 が隆起してきたため近医受診し，生検にて SCC と診断された。同年 11 月中部労災病院形成外科 にて切除術施行するも, 2000 年 1 月に右鼠径リ ンパ節に転移を認め, 同リンパ節郭清術が施行 された。その後, 同年 9 月に愛知医大皮膚科入 院となった。

現症( 1998年中部労災病院受診時): 右下腿外 側に $6 \mathrm{~cm}$ 大の比較的境界明瞭な黒褐色から淡 紅色の一部びらんを伴う局面があり，その中央 よりやや下方に $3 \mathrm{~cm}$ 大の腫瘤を認める (図 1 )。

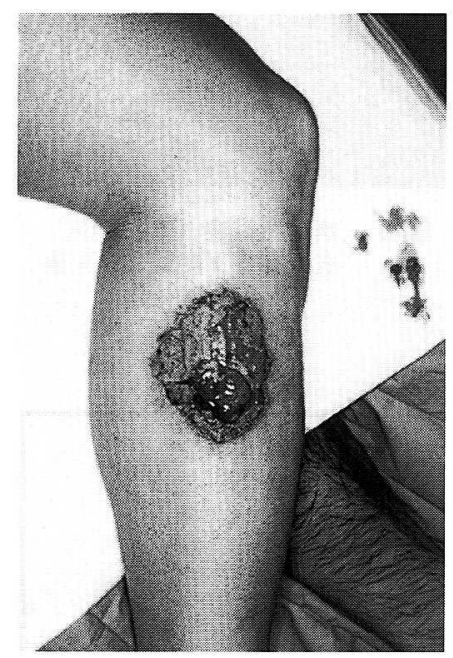

図 1. 初診時臨床像

組織学的所見 (1998 年切除標本): 腫瘤辺縁 の湿潤局面の表皮細胞は大小不同で配列は乱 れ，核異型があり核分裂像も散見されボーエン 病の像を呈していた（図2a）。腫瘤部辺縁では表 皮から真皮に向かって腫湯胞巣の浸潤が認めら れた。腫瘤部では大小不同の腫瘍胞巣が皮下組
織まで浸潤し，そこには核分裂像や異常角化細 胞も認められた（図2b)。また腫瘍組織の一部に は，好塩基性の胞体を持ち異型がより高度な低 分化の腫瘍胞巣が皮下組織まで浸潤していた (図 2c)。腫瘍の深さは表皮から $7 \mathrm{~mm}$ であった。
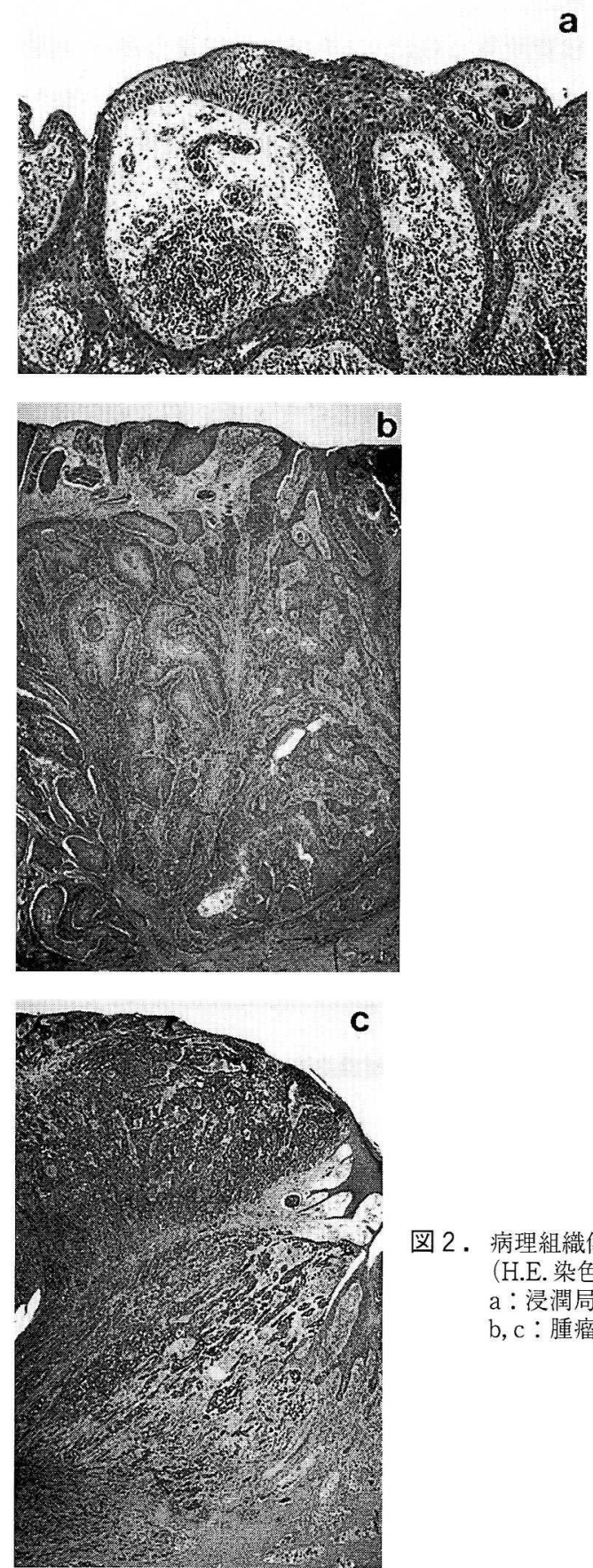

図 2.病理組織像

(H.E. 染色) $\mathrm{a}$ : 浸潤局面部 $\mathrm{b}, \mathrm{c}$ ：腫瘤部 
以上の臨床経過および組織学的所見よりボー エン病から進展したSCC stage II $\left(\mathrm{T}_{2} \mathrm{~N}_{0} \mathrm{M}_{0}\right)$ と 診断，辺縁より $2 \mathrm{~cm}$ 離し，深部は筋膜を含めて 切除し植皮術が施行された。

その後 2000 年 9 月に愛知医大皮虐科入院と なった。

検査所見：Ga シンチでは左鎖骨上窩・両肺 門 ・縦隔リンパ節と右大腿に多数の hot spots がみられ, 腰椎・右大腿頸部にも腫瘍の骨転移 と思われる集積が認められた。またCTでは両 側胸水と腹水が認められた。血中の CYFRA は $5.1 \mathrm{ng} / \mathrm{m} l$ (正常值 $2 \mathrm{ng} / \mathrm{m} l$ 以下) と高値を示して いた。

入院後の経過（表 1 ）: 愛知医大入院時, 右頸 部リンパ節腫張と腹部に 1 力所, 右大腿に 3 力 所の約 $1 \mathrm{~cm}$ 大の皮下結節が認められた。右大腿 皮下結節の 1 力所を生検したところ好塩基性に 染まる核小体の目立つ大型な核を有する細胞で 核分裂像も多数認められ，低分化な SCC の皮虐 転移を認めた（図３）。

入院彴より腰痛が増強したため腰椎転移部に 放射線療法を施行したところ腰痛は軽度軽快す るも明らかな改善は認められなかった。またシ スプラチン (CDDP) 100mg およびフルオロウラ シル (5FU) 1000mgによる化学療法を開始し,
腹部・右大腿の皮下結節㧍よび頸部リンパ節腫 張は消退したが，2クール終了後に腎機能の低 下を認めたためCDDPをカルボプラチン (CBDA) 300mg に変更した。その後, 肝機能障 害·胸水・腹水が出現し, 入院 4 力月後の 2001 年 1 月 13 日に肺水腫 - 心不全にて永眠された。

剖検所見：遠隔転移として心臓・肝臓・両 肺 - 脾臓 - 膵臓・腎臓・横隔膜 - 小腸 - 大腸 大動脈に粟粒大から指頭大の結節を多数認め, 胸骨 · 胸椎 (Th 2.5.11.12) · 腰椎 (L4.5) と気 管支リンパ節への転移も認められた。

また癌性の腹膜炎や胸膜炎さらに心外膜炎も 認められ，これらが直接の死因と考えられた。

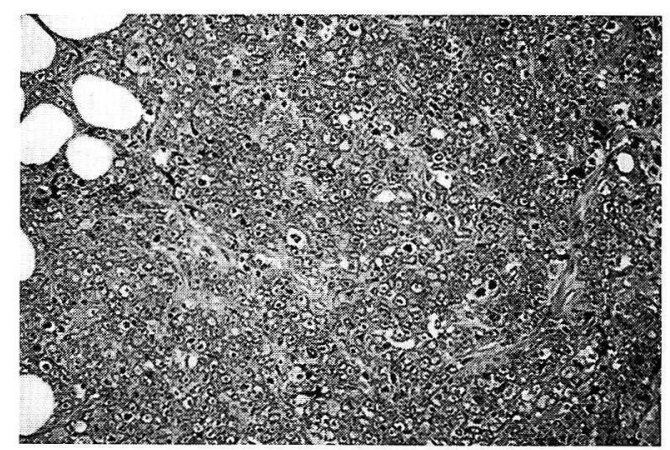

図 3. 病理組織像 (H.E. 染色) 右大腿皮下結節より生検

表 1 . 入院後の臨床経過

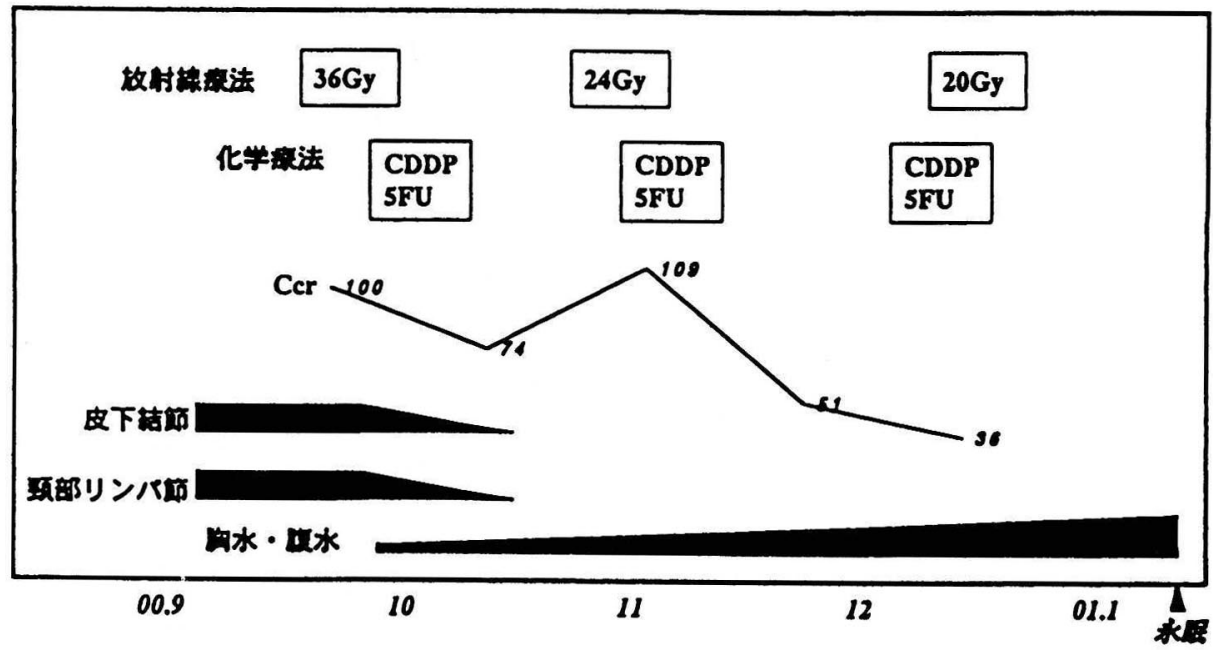




\section{考案}

皮膚扁平上皮癌の前駆病変の 1 つとしてボー エン病がある。ボーエン病が真皮へ浸潤，つま り癌化した場合の臨床像としては, 落屑性紅斑 や色素斑に数週間から数年の経過で急速に成長 する腫瘤が特徵とされる11。自験例でもびらん 局面が存在して約 3 年の経過で急速に増大する 腫瘤が出現している。

組織学的にボーエン病が癌化する時は，多く はSCC の方向に向かうとされ ${ }^{2)}$, 自験例でも腫 瘤部はSCC の組織像であったが, 好酸性に染ま る腫瘍細胞と好塩基性に染まる低分化な腫瘍細 胞が混在し，深さは皮下組織にまで及んでい た。また，一般的に原発巣と転移巣は組織学的 に同じ像を示すが，自験例では所属リンパ節や 皮膚などの転移部では，一見リンフォーマを思 わせるほどで原発巣よりも低分化な組織像を呈
していた。

$\mathrm{Alam}^{3)}$ らは皮膚扁平上皮癌に打ける再発と 転移のリスクファクターとそれらの相対危険率 を報告している（表 2 ）。相対危険率は $2 \mathrm{~cm}$ 以 下の SCC が再発や転移を起こす危険率を 1 と して評価してあり，データが不十分な部分はー (dash) で示してある。自験例では臨床的に腫瘍 は急速に成長し, $3 \mathrm{~cm}$ と大きく,組織学的に $7 \mathrm{~mm}$ の深さがあり，かつ低分化型という多くのリス クファクターが認められた。術後約 1 年で所属 リンパ節に転移，まもなく全身諸藏器にも転移 を認め, その 1 年後には死亡という急速な経過 をたどったのは，これらのリスクファクターを 多く備えていたためと考えられた。以上のこと から腫瘍が完全切除されていたとしてもリスク ファクターについて検討し, 再発や転移の危険 率が高い場合は所属リンパ節廓清や放射線照射 など積極的な治療を考慮すべきであると考え た。

表 2，皮䖉扁平上皮癌におけるリスクファクターと相対危険率

\begin{tabular}{|c|c|c|}
\hline \multirow[b]{2}{*}{ Variable } & \multicolumn{2}{|c|}{ Relative Risk } \\
\hline & Recurrence & Metastasis \\
\hline \multicolumn{3}{|l|}{ Cllnical foatures } \\
\hline - Rapld growth & - & - \\
\hline - Size>2cm & 2 & 2 \\
\hline \multicolumn{3}{|l|}{ Site } \\
\hline Lip & 2 & 3 \\
\hline Ear & 2 & 3 \\
\hline Immunosuppression & - & 2 \\
\hline History of radiation treatment & - & - \\
\hline History of treatment for SCC & 3 & 4 \\
\hline \multicolumn{3}{|l|}{ Histologle features } \\
\hline - Tumor depth >4mm & 2 & 5 \\
\hline - Poorly differentiated appearance & 2 & 3 \\
\hline Infiltratlve deep or peripheral margins & - & - \\
\hline Spindle-cell features & - & - \\
\hline Acantholytic features & - & - \\
\hline Perineural invasion & 5 & 5 \\
\hline
\end{tabular}


Skin Cancer Vol. 16 No. 32001

\section{文献}

1) Grace, F. Kao : Carcinoma Arising in Bowen's Disease. Arch Dermatol, 122 : 1124-1126, 1986.
2）上野賢一, 横山文男, 儀保元惟, 他 : 本邦におけ る Bowen 病の統計的観察. 皮虐臨床, 10:909-916, 1968.

3) Murad Alam, Desiree Ratner : Cutaneous Squamous-Cell Carcinoma. N. Engl. J. Med., 344 : 975983, 2001. 